\title{
Histopathological findings and detection of parasites in the eyes of dogs infected naturally with Leishmania chagasi
}

\author{
Achados histopatológicos e deteç̧ão de parasitas nos olhos de cães infectados por Leishmania chagasi
}

\author{
Fábio Luiz da Cunha Brito ${ }^{\mathrm{I}}$ José Luiz Laus ${ }^{\mathrm{II}}$ Wagner Luiz Tafuri' ${ }^{\mathrm{II}}$ Maria Marta Figueiredo ${ }^{\mathrm{III}}$ \\ Valdemiro Amaro Silva Júnior ${ }^{\mathrm{IV}}$ Frederico Celso Lyra Maia $^{\mathrm{IV}}$ Leucio Câmara Alves $^{\mathrm{IV}}$
}

\begin{abstract}
The objective of the present study was to investigate the histopathological alterations and detection of parasites that occur in the eyes of dogs naturally infected with Leishmania chagasi. The eyes of 25 dogs with a positive parasitological and serological exam for $\mathbf{L}$. chagasi were submitted to routine ophthalmic examination. Fragments were obtained from the eyeball and were analyzed by immunohistochemistry and histopathology. Among the structures studied, the conjunctiva of the third eyelid was the tissue most frequently stained for $\boldsymbol{L}$. chagasi. Histopathological analysis revealed a predominantly mononuclear inflammatory infiltrate whose intensity ranged from discrete to intense in the various ocular structures. Vascular congestion and perivasculitis were also observed. The histopathological alterations that occur in the eyeball of dogs with visceral leishmaniasis might be related to the presence of antibodies.
\end{abstract}

Key words: canine, Leishmaniasis, ocular abnormalities, histopathology, immunohistochemistry.

\section{RESUMO}

O objetivo deste trabalho foi estudar as alterações histopatológicas e a detecção do parasito nos olhos de cães naturalmente infectados por Leishmania chagasi. Utilizaramse os olhos de 25 cães com exame parasitológico e sorológico positivo para Leishmania chagasi. Os animais foram submetidos à semiotécnica oftálmica rotineira. Fragmentos do globo ocular foram coletados e destinados à imunoistoquímica $e$ histopatologia. Entre as estruturas avaliadas, a conjuntiva da terceira pálpebra foi a que mais demonstrou imunomarcação da Leishmania chagasi. Na avaliação histopatológica, foi observado predominantemente infiltrado inflamatório mononuclear, variando de discreto a intenso nas diversas estruturas oculares. Congestão vascular e perivasculite também foram observadas. As alterações histopatológicas do bulbo do olho em cães com leishmaniose visceral podem estar relacionadas à presença do anticorpo.

Palavras-chave: cão, Leishmania, anormalidades oculares, histopatologia, imunoistoquímica.

\section{INTRODUCTION}

In addition to primary ophthalmopathies, systemic disorders such as immune-mediated, metabolic, infectious, parasitic and neoplastic diseases may result in ophthalmic alterations. Among these diseases, visceral leishmaniasis has raised great interest due to complications the disease causes in animals and its risks for public health in view of its clinical manifestation in humans.

The incidence of ocular lesions caused by visceral leishmaniasis is apparently higher in dogs than in humans and these lesions represent an important research field. These lesions might be the result of direct ocular parasitism but immune-mediated mechanisms have also been reported (KOUTINAS et al., 1999). Some investigators found that ocular disease can be uni- or bilateral and even cause more than one

\footnotetext{
'Proimagem - Diagnóstico Veterinário: Serviço de Oftalmologia Veterinária, Rua Tenente João Cícero, 390, Boa Viagem, 51020190, Recife, PE, Brasil. E-mail: fabiobrito@click21.com.br. Autor para correspondência

IIDepartamento de Clínica e Cirurgia Veterinária, Faculdade de Ciências Agrárias e Veterinárias (FCAV), Universidade Estadual Paulista (UNESP), Jaboticabal, SP, Brasil.

IIIInstituto de Ciências Biológicas, Universidade Federal de Minas Gerais (UFMG), Belo Horizonte, MG, Brasil

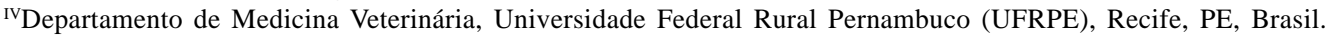


alteration in the same eye (PEÑA et al., 2000; BRITO, 2004). Studies have shown that both segments of the eye might be affected, but that lesions predominate in the anterior segment (MOLLEDA et al., 1993; BRITO, 2004; BRITO et al., 2004). Histopathological alterations can affect different structures of the eye and are mainly characterized by the presence of an inflammatory infiltrate and, less commonly, by amastigote forms of the parasite, which permeates ocular tissues (MOLLEDA et al., 1993; LAUGIER \& VERROBOULANGER, 1992; GARCÍA-ALONSO et al., 1996).

Canine visceral leishmaniasis has been reported in various countries and represents an important disease in canine clinical practice, in addition to the problems this disease causes to public health. In Brazil, canine kala-azar plays an important role in small animal practice due to the growing diagnosis of associated ophthalmopathies (BRITO et al., 2004). The conditions involved in the pathogenesis of ocular events in dogs infected with Leishmania chagasi are still a matter of controversy. Therefore, the objective of the present study was to investigate the pathological conditions that occur in the eyes of dogs with ophthalmopathies resulting from natural infection with L. chagasi.

\section{MATERIAL AND METHODS}

Twenty-five dogs infected naturally with a positive parasitological exam for $\mathbf{L}$. chagasi (bone marrow aspiration biopsy) and positive serology for indirect immunofluorescence were included in the study (BRITO, 2004). The animals were submitted to routine ophthalmic examination including the Schirmer Tear Test $^{\mathrm{a}}$, slit-lamp biomicroscopy ${ }^{\mathrm{b}}$, applanation tonometryc ${ }^{\mathrm{c}}$, indirect binocular ophthalmoscopy ${ }^{\mathrm{d}}$, and fluorescein teste. Positive dogs were submitted to active euthanasia with high doses of pentobarbital according to the guidelines of the Brazilian Ministry of Health for the control of canine visceral leishmaniasis.

Fragments were obtained from the third eyelid, third eyelid gland, conjunctiva, sclerocorneal limbus, sclera, cornea, iris, ciliary body, choroid, retina, and optic nerve and analyzed by immunohistochemistry and histopathology. Prior to immunohistochemistry of the anterior uvea, melanin depigmentation was performed to minimize background effects between pigments and immunostaining using oxalic acid $5 \%$ and potassium permanganate. Immunohistochemistry was performed as described by TAFURI et al. (2004).

In order to identify an eventual correlation between the degree of parasitism and the intensity of inflammation in the ocular structures, the findings were classified quantitatively by attributing a score from 0 to 3 , where $0=$ absent, $1=$ discrete, $2=$ moderate and $3=$ intense, and correlations were determined using Spearman's correlation coefficient.

\section{RESULTS}

The results of the detection of parasite by immunostaining for Leishmania amastigotes are shown in table 1. Only in the optic nerve, retina or choroid no detection of parasite in the immunostaining was observed.

For quantitative analysis of parasitism in ocular tissues, the immunohistochemical detection was classified into different degrees ranging from absent to intense as shown in the figure 1. Among the structures ocular conjunctiva of the third eyelid showed the greatest degree of parasitism (Figure 2A).

In all animals the type of inflammatory infiltrate was predominantly lymphoplasmacytic. The quantitative analysis of inflammatory infiltrate in ocular tissues was classified into different degrees ranging from absent to intense as shown in the figure 3.

Evaluation of histological sections of the cornea showed disorganization of the corneal stroma, with vascular proliferation in the transition area with the limbus, and the presence of some vessels in the stroma. Moreover, hyperplasia of the anterior epithelium and basement membrane and increased number of fibroblasts in the subepithelial area was observed. When present, the inflammatory exudate was discrete, located adjacent to the anterior epithelium, and mainly consisted of plasma cells.

A more intense inflammatory infiltrate was observed in connective tissue areas adjacent to the epithelium. Furthermore, ulceration of the epithelium accompanied by the presence of fibrin was noted, especially when the cell infiltrate was severe. Hyperplasia of the epithelium and basement membrane and epithelial cells projecting into the stroma were also noted.

Lymphocytes, plasma cells and macrophages were observed around blood vessels, a finding which characterizes perivasculitis, notably at the sclerocorneal junction. Vascular congestion associated or not with the dilatation of vessels, especially those located in the drainage angle, was also observed. Vascular congestion and vessel dilatation were noted in the sclera, which contained protein material and red blood cells. Although uncommon, vascular proliferation was present in the cornea. There was a predominance of lymphoplasmacytic elements, 
Table 1 - Absolute (AF) and relative (RF) frequencies, the immunehistochemical for marking amastigotas forms of Leishmania chagasi in ocular tissues of dogs naturally infected with Leishmania chagasi.

\begin{tabular}{|c|c|c|c|c|c|c|c|c|c|c|}
\hline \multirow{3}{*}{ Eyes } & \multirow{2}{*}{\multicolumn{2}{|c|}{----------A---------- }} & \multirow{2}{*}{\multicolumn{2}{|c|}{-----------B----------- }} & \multirow{2}{*}{\multicolumn{2}{|c|}{-----------C----------- }} & \multirow{2}{*}{\multicolumn{2}{|c|}{-----------D----------- }} & \multirow{2}{*}{\multicolumn{2}{|c|}{----------E---------- }} \\
\hline & & & & & & & & & & \\
\hline & $\mathrm{AF}$ & RF (\%) & $\mathrm{AF}$ & RF (\%) & $\mathrm{AF}$ & RF (\%) & $\mathrm{AF}$ & RF (\%) & $\mathrm{AF}$ & RF (\%) \\
\hline Right eyes & 01 & 04 & - & - & 09 & 36 & - & - & - & - \\
\hline Left eyes & 02 & 08 & - & - & 05 & 20 & - & - & - & - \\
\hline Both eyes & 03 & 12 & - & - & 09 & 36 & 05 & 20 & - & - \\
\hline Positive total & 06 & 24 & - & - & 23 & 92 & 05 & 20 & - & - \\
\hline
\end{tabular}

* A - corneal/limbal/escleral / B - optical nerve / C - conjunctival/third eyelid gland / D - iris/ciliar body / E - choroid /retina.

with few polymorphonuclear. Less constantly among collagen fibers in the stroma and lining epithelium. A lymphoplasmacytic inflammatory infiltrate was frequently identified around vessels of the sclera (perivasculitis) and scattered among collagen fibers.

The lining epithelium of the third eyelid was found to be thin in most animals and sometimes it was ulcerated. Despite the predominance of lymphoplasmacytic cells, neutrophils were present in small numbers. Plasma cells and macrophages predominated in subepithelial areas and were rare in the epithelial interstitium. These findings were mainly observed in simple stratified epithelium and, at a lower intensity, in deeper areas of the stroma, as well as, in prismatic columnar epithelium. Hyperplasia of goblet cells, metaplasia associated with the absence of goblet cells, and keratinization were observed in this epithelium. The formation of intraepithelial glands, most of them containing active cells, was noted in regions without metaplasia (Figure 2B).

Plasma cells, superficial surrounding macrophages and deep vessels of the conjunctiva were observed, which resulted in intense and diffuse perivasculitis accompanied or not by vascular congestion. Apoptotic figures in the tissue conjunctive were also frequent, in addition to a large number of active plasma cells, histiocytes and macrophages permeating the stroma. Lymphoid nodules present in the conjunctiva of the third eyelid were found to be enlarged, contained no germinative centers and presented mitotic figures.

Focal or diffuse atrophy of serous and mucous acini, accompanied by a lymphoplasmacytic cellular exudate, was the main alteration. Atrophy was

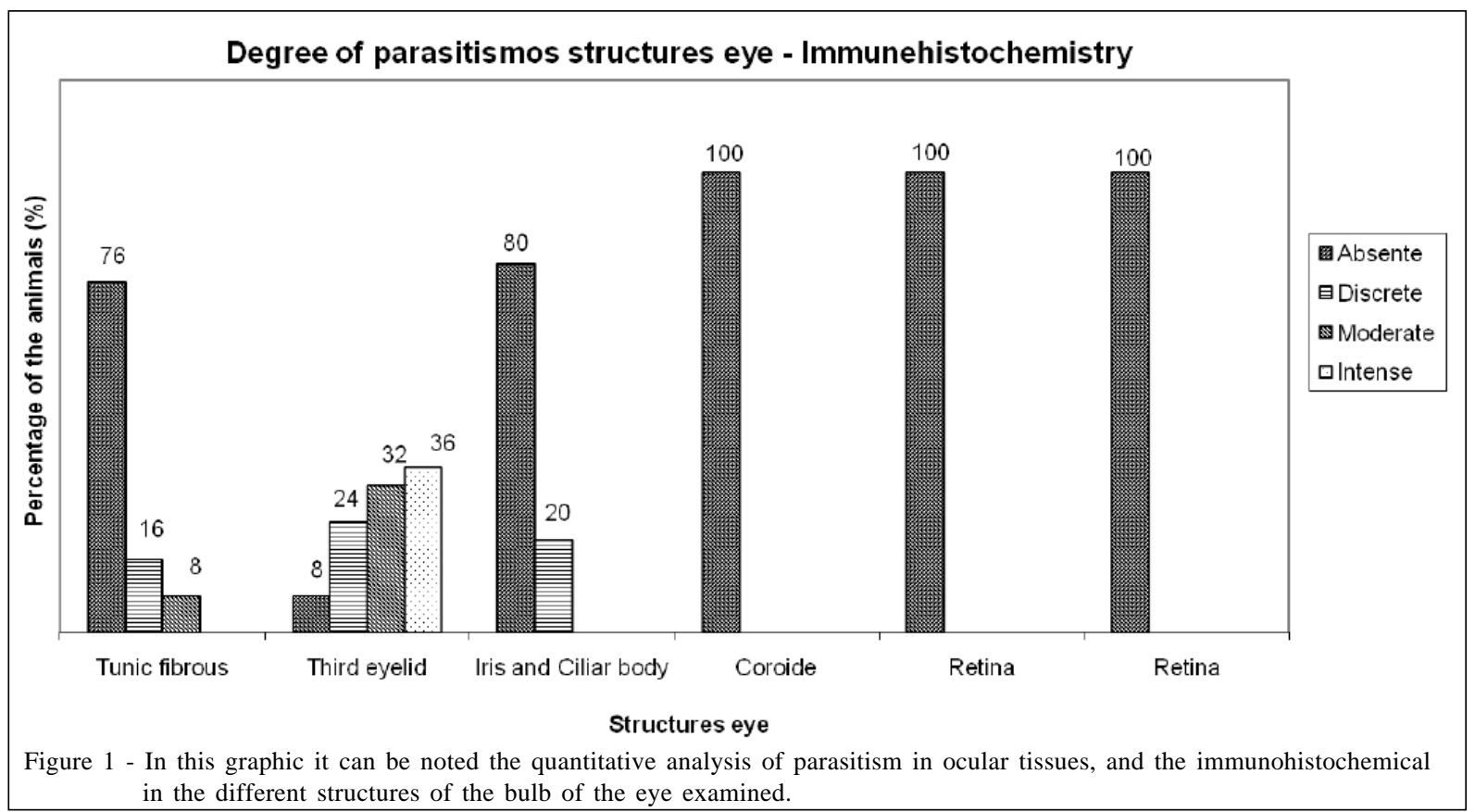

Ciência Rural, v.40, n.5, mai, 2010. 


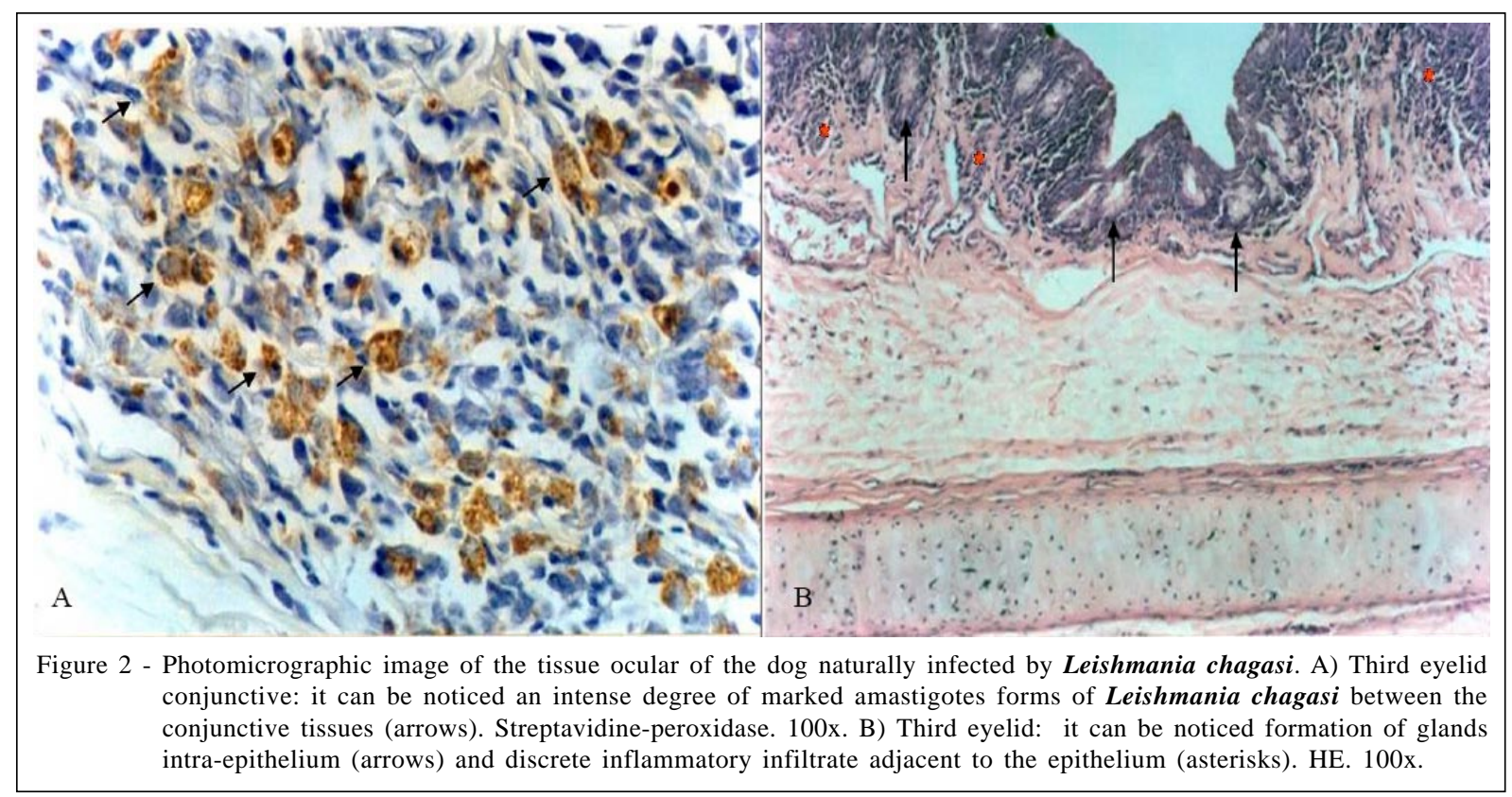

even more evident when contiguous to the inflammatory infiltrate. Inflammatory cells were visible among acini and in the lumen and ducts. Plasma cells and macrophages were observed in the periductal region and in extralobular ducts and were associated with gland hyperplasia. In addition, cystic dilatation of the ducts and invasion of the acinar parenchyma by adipocytes were noted.

The most common findings in the iris, ciliary body and ciliary processes were vascular congestion, edema and perivasculitis, notably characterized by the presence of plasma cells and macrophages. In the ciliary processes, hemorrhage and fibrin deposition were observed. In the ciliary body, fibrosis and muscle fiber hyperplasia concomitantly with hemorrhage were also noted. In two animals, inflammatory cells (plasma cells, macrophages, monocytes and degenerated neutrophils) together with red blood cells were identified migrating from the iris and ciliary body to the aqueous humor.

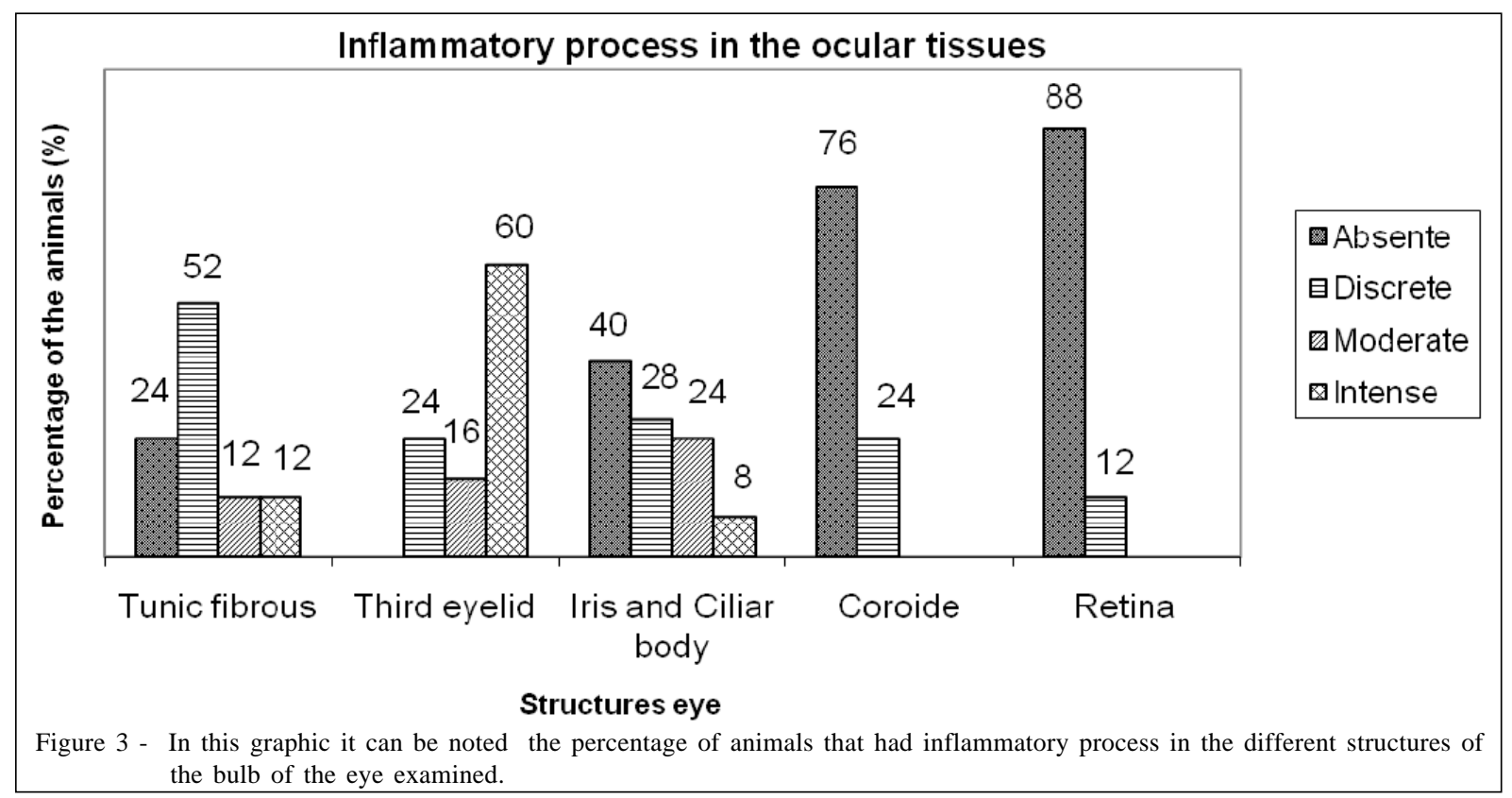

Ciência Rural, v.40, n.5, mai, 2010. 
In the choroid, the findings repeated those observed in the anterior uvea. Vascular congestion was the predominant alteration in the retina. The concomitant presence of inflammatory cells in the retina and choroid characterized chorioretinitis. Inflammatory cells were notably found among layers of optic nerve fibers and ganglion cells, or even among the external plexiform and ganglion cell layers. In addition to the inflammatory exudate, these animals also presented an enlarged optic nerve fiber layer and ganglion cell degeneration and necrosis.

Analysis of the correlation between inflammation and the presence of parasites in the ocular structures using Spearman's correlation coefficient revealed a significant correlation for the tunica fibrosa ( $\mathrm{R}=0.760609)$, third eyelid $(\mathrm{R}=0.958403)$ and anterior uvea $(\mathrm{R}=0.766652)$. However, no correlation was observed for the choroid $(\mathrm{R}=0)$ or retina $(\mathrm{R}=0)$.

\section{DISCUSSION}

In the present study, amastigote forms of $\boldsymbol{L}$. chagasi were detected in ocular tissues of infected animals, except for the retina. The use of hematoxylineosin staining for the study of the eyes of 12 dogs naturally infected with $\mathbf{L}$. chagasi, observed parasitism in structures such as cornea, sclera, conjunctiva, iris and retina (DIAS, 1998).

One explanation for the finding of amastigote forms in the cornea is the occurrence of corneal inflammation prior to the presence of the parasite which would be transported to the cornea by parasitized macrophages, notably to the inflammation site. On the other hand, the presence of amastigotes in the conjunctiva is probably due to the immune function of this structure which acts as a lymphoid tissue.

In animals in which amastigote forms of Leishmania sp. were detected in the ciliary body and iris, uveitis was present, and staining of the parasite was discrete. The presence of Leishmania amastigotes in ocular structures has also been investigated by immunohistochemistry in two dogs with uveitis, in which parasite forms were detected in the lacrimal duct, ciliary body and processes, iris and sclera (GARCÍAALONSO et al., 1996). The presence of the parasite in intraocular tissues is probably due to the breakdown of the blood-aqueous humor barrier and its passage to the anterior chamber or migration inside parasitized macrophages.

The absence of Leishmania amastigote forms in the retina and optic nerve might be related to tropism of the parasite for certain tissues or to the presence of the blood-retina barrier. Amastigotes have not been commonly reported in nervous tissue.
The degree of parasitism was not uniform among the ocular structures studied or even in the same structure, or between the right and left eye. Previous studies also suggested an unequal distribution of parasites in the skin of dogs (LIMA et al., 2003; TRAVI et al., 2001). The unequal distribution of parasites observed in the eyeball is probably due to the independent response of each eye to aggression by the pathogen.

Predominantly cellular exudation mainly consisting of macrophages, plasma cells and lymphocytes was one of the alterations observed in the tunica fibrosa, conjunctival tissue, tunica vascularis and retina of dogs naturally infected with $\boldsymbol{L}$. chagasi. Lymphoplasmacytic infiltration has been observed in various organs such as skin, spleen, liver, intestine, lung and kidneys (SILVA, 1997; TAFURI et al., 2001; XAVIER, 2002) in addition to structures of the eyeball (GARCIA-ALONSO et al., 1998; MOLLEDA et al., 2003; NARANJO et al., 2005).

The intensity of inflammation varied between animals and between the ocular tissues studied, ranging from the absence of inflammatory cells to manifestations of intense exudation. The difference in the intensity of inflammation is probably due to the type of host immune response (cellular or humoral), similar to what has been described for the skin (XAVIER, 2002). Although the eyeball is a single structure, the immune response of its different components is variable. The conjunctiva and uvea represent the primary centers of lymphoid activity in the eye. However, antigens are processed in the conjunctiva. There are specialized areas in the conjunctiva, called conjunctival associated lymphoid tissue, which receive and present antigens (EICHENBAUM et al., 1987). In view of this specific response, the main sites of inflammation were the ocular surface and uveal tract.

In the retina, no parasites were observed that would explain inflammatory manifestations. PUMAROLA et al. (1991) and CIARAMELLA et al. (1997) reported vascular lesions in dogs with visceral leishmaniasis triggered by the localized or disseminated deposition of immune complexes in the blood vessel wall. The possibility of deposition of immune complexes in the retina, triggering an inflammatory response and the occurrence of lesions, cannot be ruled out.

In the present study, intense inflammatory exudation was observed in the lacrimal apparatus and was characterized by abundant granulation, focal and diffuse infiltration and a large number of Leishmania sp. amastigotes inside macrophages, in addition to generalized epithelial necrosis, findings also described (MOLLEDA et al., 1993; GARCIA-ALONSO et al., 1998). 
In addition to the presence of the parasite and of inflammatory cells themselves, another factor that should be taken into account in the formation of tissue injury are substances released into the tissues by inflammatory cells. In addition to their participation in the elimination of the aggressive agent, macrophages may trigger tissue destruction by the release of oxygen free radicals, enzymes and cytokines (SIQUEIRA JUNIOR, 2000).

Histopathology permitted the characterization of the alterations that occurred in the tunica fibrosa, such as dilatation of lymphatic vessels, thrombosis and perivasculitis, were also previously reported (MOLLEDA et al., 1993; GARCIA-ALONSO et al., 1998). However, in the present study stromal disorganization, ulceration of the corneal epithelium and epithelial and basement membrane hyperplasia, which are common alterations, did not occur at the same proportion as reported by other investigators (MOLLEDA et al., 1993; GARCIA-ALONSO et al., 1996; DIAS, 1998).

With respect to the nictitating membrane, an intense infiltrate was detected in the subepithelial region, surrounding lymphoid follicles, and in the secretory ducts. In addition, atrophy of the serous and mucous acini was the predominant alteration. Inflammation associated with acinar and ductal alterations has been suggested to be related to the deficit in tear production observed in canine visceral leishmaniasis (NARANJO et al., 2005). The main findings in the third eyelid gland were granulomatous or pyogranulomatous infiltrates mainly located around ducts and the marked presence of macrophages, lymphocytes and plasma cells. GARCIA-ALONSO et al. (1996), describing the histopathological alterations in two dogs with visceral leishmaniasis, observed an intense inflammatory reaction characterized by granulation around the lacrimal ducts and a predominance of lymphocytes, plasma cells and macrophages, associated with epithelial necrosis and partial epithelial ulceration.

The alterations observed in the present study in the lymphoid nodules and goblet cells of the conjunctiva have not been previously reported (MOLLEDA et al., 1993; GARCIA-ALONSO et al., 1998; DIAS, 1998; NARANJO et al., 2005). These conditions are probably the result of the intense inflammatory response observed in these structures.

In visceral leishmaniasis, intraocular inflammation may result from the intense presence of leukocytes and Leishmania amastigote-like forms as described for the skin (MOZOS et al., 1999) or from the immune-mediated response (type III hypersensitivity) triggered by Leishmania antigens and by specific and nonspecific immunoglobulin deposits as observed for the glomerular filtration barrier (SARTORI et al., 1987; NIETO et al., 1992).

In the present study, some animals showed no histopathological alterations in the eyeball. This finding might be related to the type of immune response manifested by the host. Animals presenting a cellular (Th1) response are able to elicit a greater cellular response and to overcome infection with Leishmania sp., whereas animals developing a humoral (Th2) immunological response might become intensely parasitized (ABRANCHES et al., 1991; PINELLI et al., 1994; NOLI, 1999).

\section{CONCLUSION}

The present results showed that immunohistochemistry is a suitable technique for the determination of parasites in the ocular structures of dogs naturally infected with L. chagasi. Histopathological analysis revealed the predominance of an inflammatory infiltrate consisting of lymphocytes, macrophages and plasma cells, characterizing perivasculitis that was also distributed diffusely between tissues.

\section{SOURCES OF MANUFACTURES}

a - Schirmer tear test - Ophthalmos, Ribeirão Preto, SP, Brazil. b - Slit lamp - Kowa Company Ltd.

c - Applanation tonometer (Tono-pen) - Mentor Medical Systems.

d - Indirect binocular ophthalmoscope (Omega 180) - Heine Optotechnik.

e - Fluorescein - Ophthalmos, Ribeirão Preto, SP, Brazil.

\section{ACKNOWLEDGEMENTS}

We would like to thank to the Fundação de Amparo a Pesquisa do Estado de São Paulo (FAPESP) for the financial support for accomplishment of this research on the process number 04/11718-0.

\section{ETHICS COMMITTEE ON ANIMAL EXPERIMENTATION}

The study was approved by the Ethics Committee and the bioethical guidelines established by the Association for Research in Vision and Ophthalmology (ARVO) .

\section{REFERENCE}

ABRANCHES, P. et al. An experimental model for canine visceral leishmaniasis. Parasite Immunology, v.13, p.537-550, 1991. Available from: <http://www3.interscience.wiley.com/cgi-bin/ fulltext/119991893/PDFSTART>. Accessed: mar. 15, 2010. doi: 10.1111/j.1365-3024.1991.tb00550.x. 
BRITO, F.L.C. Alterações oculares e análise do humor aquoso de cães (Canis familiaris LINNAEUS, 1758) infectados naturalmente por Leishmania chagasi (CUNHA \& CHAGAS, 1937). 2004. 53f. Dissertação (Mestrado em Ciência Veterinária) - UFRPE, Recife, PE.

BRITO, F.L.C. et al. Uveitis associated by Leishmania chagasi in dog from Olinda City, Pernambuco, Brazil. Ciência Rural, v.34, n.3, p.925-929, 2004. Available from: <http://www.scielo.br/ scielo.php?pid=S0103-84782004000300042\&script=sci_arttext $>$. Accessed: mar. 15, 2010. doi: 10.1590/S010384782004000300042 .

CIARAMELLA, P. et al. A retrospective clinical study of canine leishmaniasis in 150 dogs naturally infected by Leishmania infantum. Veterinary Record, v.141, p.539543, 1997.

DIAS, D.V. Leishmaniose visceral canina: estudo parasitológico, imunológico e histopatológico em olhos de cães. 1998. 117f. Tese (Doutorado em Patologia) UFMG, Belo Horizonte, MG.

EICHENBAUM, J.D. et al. Immunology of the ocular surface. Immunology, v.9, n.11, p.99-106, 1987.

GARCÍA-ALONSO, M. et al. Immunopathology of the uveitis in canine leishmaniasis. Parasite Immunology, v.18, p.617623, 1996. Available from: <http://www3.interscience.wiley.com/ cgi-bin/fulltext/119211390/PDFSTART>. Accessed: mar. 15, 2010. doi: 10.1046/j.1365-3024.1996.d01-39.x.

GARCIA-ALONSO, M. et al. Patología ocular asociada a leishmaniosis canina. Consulta de Difusión Veterinária, v.6, n.54, p.49-53, 1998.

KOUTINAS, A.F. et al. Clinical considerations on canine visceral leishmaniasis in Greece: A retrospective study of 158 cases (1989-1996). Journal American Animal Hospital Association, v.35, p.376-383, 1999.

LAUGIER, C.; VERRO-BOULANGER, C. Ocular leishmaniasis. Pratique Medicale e Chirurgicale del Animal e Campagnie, v.27, n.6, p.751-752, 1992.

LIMA, V.M.F. et al. Anti-leishmania antibodies in cerebrospinal fluid from dogs with visceral leishmaniasis. Brazilian Journal of Medical and Biological Research, v.36, n.4, p.485-489, 2003.

MOLLEDA, J.M. et al. Clinical and histopathological study of the eye in canine leishmaniasis. Israel Journal Veterinary Medicine, v.48, p.173-178, 1993.

MOZOS, E. et al. Leishmaniosis and generalized demodicosis in three dogs: a clinicopathological and immunohistochemical study. Journal of Comparative Pathology, v.120, p.257268, 1999.

NARANJO, C. et al. Characterization of lacrimal gland lesions and possible pathogenic mechanisms of keratoconjunctivitis sicca in dogs with leishmaniasis. Veterinary Parasitology, v.133, p.37-47, 2005.
NIETO C.G. et al. Pathological changes in kidneys of dogs with natural Leishmania infection. Veterinary Parasitology, v.45, p.33-47, 1992.

NOLI, C. Canine leishmaniasis. Waltham Focus, v.9, n.2, p. 16-24, 1999.

PEÑA, M.T. et al. Ocular and periocular manifestations of leishmaniasis in dog: 105 cases (1993-1998). Veterinary Ophthalmology, v.3, p.35-41, 2000. Available from: <http:/ /www3.interscience.wiley.com/cgi-bin/fulltext/119051280/ PDFSTART>. Accessed: mar. 15, 2010. doi: 10.1111/j.14635224.2000.00106.x.

PINELLI, E. et al. Cellular and humoral immune responses in dogs experimentally and naturally infected with Leishmania infantum. Infection and Immunity, v.62, p.229-235, 1994.

PUMAROLA, M. et al. Canine leishmaniasis associated with systemic vasculitis in two dogs. Journal Comparative Pathology, v.105, p.279-286, 1991.

SARTORI, A. et al. Immune complexes in experimental Kalaazar. Parasite Immunology, v.9, p.93-103, 1987.

SILVA, J.C.F. Leishmaniose visceral canina no município de Montes Claros, Minas Gerais, Brasil. 1997. $45 \mathrm{f}$. Dissertação (Mestrado em Patologia) - UFMG-Belo Horizonte, MG.

SIQUEIRA JUNIOR, J.F; DANTAS, C.J.S. Mecanismos celulares e moleculares da inflamação. São Paulo: MEDSI, 2000. 238p.

TAFURI, W.L. et al. An alternative immunohistochemical method for detecting Leishmania amastigotes in paraffin-embedded canine tissues. Journal Immunology Methods, v.292, p.17-23, 2004. Available from: < h t p : / / w w w. s c i encedirect.com / science? ob=ArticleURL\&_udi=B6T2Y-4CXKN43$1 \&$ _user $=10 \&$ \& coverDate $=09 \% 2 \mathrm{~F} 01 \% 2 \mathrm{~F} 2004 \&$ \&doc $=1$ \&_fmt $=$ high \&_orig=search\&_sort $=$ d\&_docanchor $=\&$ view $=c$

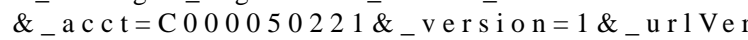
sion=0\&_userid=10\&md5=3410ad190a60a1a565969b6f3afa9369>. Accessed: abr, 13, 2010. Doi: 10.1016/j.jim2004.05.009.

TAFURI, W.L. et al. Canine visceral leishmaniosis: a remarkable histopathological picture of one case report from Brazil. Veterinary Parasitology, v.96, p.203-212, 2001. Available from: <http:// www.sciencedirect.com/science?_ob=ArticleURL\&_udi=B6TD7-42G0KJG$3 \&$ user $=5674931 \&$ coverDate $=04 \% 2$ F02\%2F2001\&_rdoc $=1 \&$ fmt=high\&_orig=search\&_sor t=d\&_docanchor=\&view=c\&_searchS $\operatorname{trId}=1250342971 \&$ _rerunOrigin $=$ google $\&$ acct $=$ C000049650 \&_version $=1 \&$ _ ur l Version $=0 \&$ _ u s e ri d $=$ 5674931\&md5=605553eced9987af1ed717afa6197d7a>. Accessed: mar. 15, 2010. doi: 10.1016/S0304-4017(00)00436-2.

TRAVI, B.L. et al. Canine visceral leishmaniasis in Colombia: relationship between clinical and parasitological status and infectivity for sand flies. American Journal of Tropical Medicine and Hygiene, v.64, n.3-4, p.119-124, 2001

XAVIER, S.C. Aspectos clínicos, histopatológicos e parasitológicos da pele de cães naturalmente infectados com Leishmania (Leishmania) chagasi. 2002. 46f. Dissertação Mestrado em Patologia) - UFMG, Belo Horizonte, MG. 